Article

\title{
Bike Station Suitability on University Campus Using Origin-Destination Matrix-A Morgan State University Case Study
}

\author{
Nashid K. Khadem, Md Muhib Kabir, Snehanshu Banerjee *(D) and Mansoureh Jeihani \\ Transportation and Urban Infrastructure Studies, Morgan State University, Baltimore, MD 21251, USA \\ * Correspondence: snban1@morgan.edu
}

Received: 24 June 2019; Accepted: 19 July 2019; Published: 21 July 2019

\begin{abstract}
In contemporary times, bike sharing programs are gaining importance as an influential transportation mode in both urban and rural areas. They are also used as a vital transportation mode on university campuses which serve as a healthy and environmentally-friendly transportation system. However, having an appropriate location for a bike station is important, so as to maximize the benefits of the service. This study used an origin-destination (O-D) matrix to identify appropriate bike station locations at the Morgan State University campus. The O-D matrix analysis identifies three locations Cumming Hall/University Health Center, Rawling Hall, and Center for Built Environment and Infrastructure Studies as the most appropriate locations to start a pilot, which will serve most of the campus (students, faculty, staff) and connect them to the maximum number of facilities at Morgan State University. The O-D matrix takes into account the occupancy or population of individual buildings based on enrollment over the past four years, the distance to the center of the campus where maximum facilities including the graduate and undergraduate offices are located, and the frequency of the university shuttle connecting most of the buildings. This methodology can be replicated and used on other university campuses and will help further bike sharing programs.
\end{abstract}

Keywords: bike-sharing system (BSS); bike station location; campus bike-share; origin-destination matrix

\section{Introduction}

In recent years, bike-sharing systems (BSS) have created their place as an attractive mode of transportation for short trips. More than 400 cities have already installed the BSS around the world and an approximate half million bikes are publicly available around the globe [1,2]. According to the global map of bike-sharing cities [3], there are 1993 active bike-share programs while 378 programs are under construction. People can take a short one-way trip whenever they need, which is also a healthy way of commuting. It also helps to increase last mile connectivity by enhancing access to public transportation modes [4]. Travel behavior studies indicate that millennials are willing to drive less and are more interested in shared transportation systems $[5,6]$. Thus, it is safe to say that bike-share is an ideal transportation mode for the people who are environmental and health conscious and prefer to do short commutes $[4,6,7]$.

In any university, transportation is a vital issue. The goal of any campus bike-share program is to provide students, faculty, and administrators access to a healthy, environmentally-friendly transport systems. Bike-share programs in different universities have shown successful implementations [6]. Most of the university campuses in the United States have a layout and land use, which is bike and pedestrian friendly [8-10]. On some urban university campuses, parking spaces are a constraint and can be expensive. Bike-share could be an ideal complement to an existing campus-supported transit system by possibly filling in the gaps where existing transit systems may not reach. It is an environmentally 
friendly transportation system compared to motor vehicles which can complement existing university shuttle systems. Bike-share can reduce carbon emissions, foster a sense of community, and increase an appreciation of the environment. Cornell University, Stanford University, Buffalo State University, Fresno State University, Georgia Tech University, MIT, University of Oklahoma, University of Vermont, and Towson University are some of the universities who have successful bike-share programs [11]. Figure 1 shows some of the universities with bike-share programs and the number of bike stations at each university.



Figure 1. Select university bike-share programs by number of bike stations.

Table 1 lists the demographics of a few universities with bike-share programs.

Table 1. Some universities who have successful bike-share programs.

\begin{tabular}{cccccc}
\hline University Name & Area (Acres) & Setting & 2019 Enrollment & Bike Racks & Bike Stations \\
\hline Yale University & 345 & City & 12,974 & 364 & 8 \\
Drexel University & 96 & Urban & 21,940 & 950 & \\
Webster University & 47 & Suburban & 12,750 & 34 & 5 \\
Cornell University & 745 & Rural & 23,016 & - & 440 \\
Stanford University & 8180 & Suburban & 17,178 & $1000+$ & 4 \\
Portland State & 50 & Urban & 27,305 & 18 & 20 \\
$\quad$ University & 1204 & Urban & 51,848 & 87 & 11 \\
University of Minnesota & 125 & Urban & 9516 & 90 & \\
Buffalo State University & 363 & Urban & 25,168 & & 12 \\
California State & 400 & Urban & 29,376 & $150+$ & 18 \\
University-Fresno & 166 & Urban & 11,466 & & \\
Georgia Tech University & 329 & Suburban & 22,705 & & \\
MIT & & Sours: & & & \\
Towson University & &
\end{tabular}


There are many success stories of campus bike-share programs. At Brandeis University, a lottery system was conducted to provide free bicycle rentals as the demand for bicycle riding among students and other professionals on campus was very high [25]. Tufts University reported positive results for their bike share program [26], while the University of New England solved their parking space problem by providing bicycles to all incoming freshmen [27]. They were able to convert the big parking lot to a basketball court and space for campus events.

There are specific criteria that need to be taken into consideration before starting a university campus bike-share program. A suitable bike station location is one of them [28]. Poor location of bike stations can compromise the success of the bike service. To facilitate more people, the distance between the stations and origin-destination points need to be small. The distance between stations also needs to be appropriate for bicycle riding [29]. To identify appropriate locations for bike stations, different studies used different methodologies. One of the popular optimization models is a facility location model used by researchers for the relocation of bicycle stations [30,31]. Chen et al. [32] used a semi-supervised feature selection method on open urban data of Washington D.C and Hangzhou, to recommend places for bike stations which have higher bike trip demand. Frade and Ribeiro [33] used a maximal covering location approach which helps locate the bike-share stations as well as the dimensions of the system. Lin and Yang [28] used a nonlinear integer program to select the optimal location of docking stations. Martineez et al. [34] consider a fleet size and bicycle relocation for a regular operating day and optimize the bike-station location through a mixed-integer linear program. Different GIS-based models like location-allocation [35] and origin-destination [36,37] are also popular methods for identifying suitable bike station locations.

In this study, appropriate bike station locations for Morgan State University community will be identified using an origin-destination (O-D) matrix, a GIS based spatial approach. Morgan State University is located in Baltimore Maryland, which used to have a bike-share program with 21 bike stations throughout downtown Baltimore [38], currently supporting dockless bikeshare programs-such as Lime, Bird, etc. According to the National Association of City Transportation Officials (NACTO) [39], the most visible component of the bike sharing system are the bike station locations. Therefore, finalizing the location of a bike station is one of the most challenging aspects of the planning process for a bike-share system. Appropriate placement of bike stations can attract riders, contribute to the holistic design of road safety, generate value for sponsors, and add activity to the realm of pedestrians. Inappropriate placement of bike-share stations can lead to inaccessibility, reduction in ridership, disruption in pedestrian, cyclist, or vehicular movements and may lead to complaints from the community [39].

\section{Materials and Methods}

\subsection{Study Area}

Morgan State University covers an area of more than 143 acres. Every year, more than 7700 students enroll at Morgan state university [40]. As of 2018, the university employs 1556 academic and 437 administrative staff. The university's academic schools and programs include the College of Liberal Arts, School of Architecture and Planning, Earl G. Graves School of Business and Management, School of Community Health and Policy, School of Computer, Mathematical, and Natural Sciences, School of Education and Urban Studies, School of Engineering, School of Global Journalism and Communication, School of Graduate Studies and School of Social Work. The administrative sections and other university resources like the graduate office, the admissions office at the Montebello complex, university student center, health center, Earl S. Richardson library, gymnasium, stadium, chapel, art gallery, student housing, and food courts. The Morgan State University study area is shown in Figure 2. Approximately 2000 students are housed in four traditional residence halls, two high rise buildings, and three apartment complexes. Baldwin Hall, Cummings Hall, Harper-Tubman House, and $\mathrm{O}^{\prime}$ Connell House are traditional style housing. Blount Towers (all female) and Rawlings Hall 
(all male) are six-eight floor high-rise residence halls. Thurgood Marshall is a co-ed apartment-style complex located on-campus while Morgan View Apartments and Marble Hall Gardens are co-ed apartment-style residence hall complexes located off-campus. Morgan View is a privatized facility that caters to Morgan State students [41]. The current university shuttle service, commonly known as 'BEARtransit', connects major university buildings on weekdays from 7:00 a.m. through 11:00 p.m. when semester is in session and 7:00 through 6:00 p.m. during spring and summer sessions. These shuttles run approximately every 15 min with no weekend service.

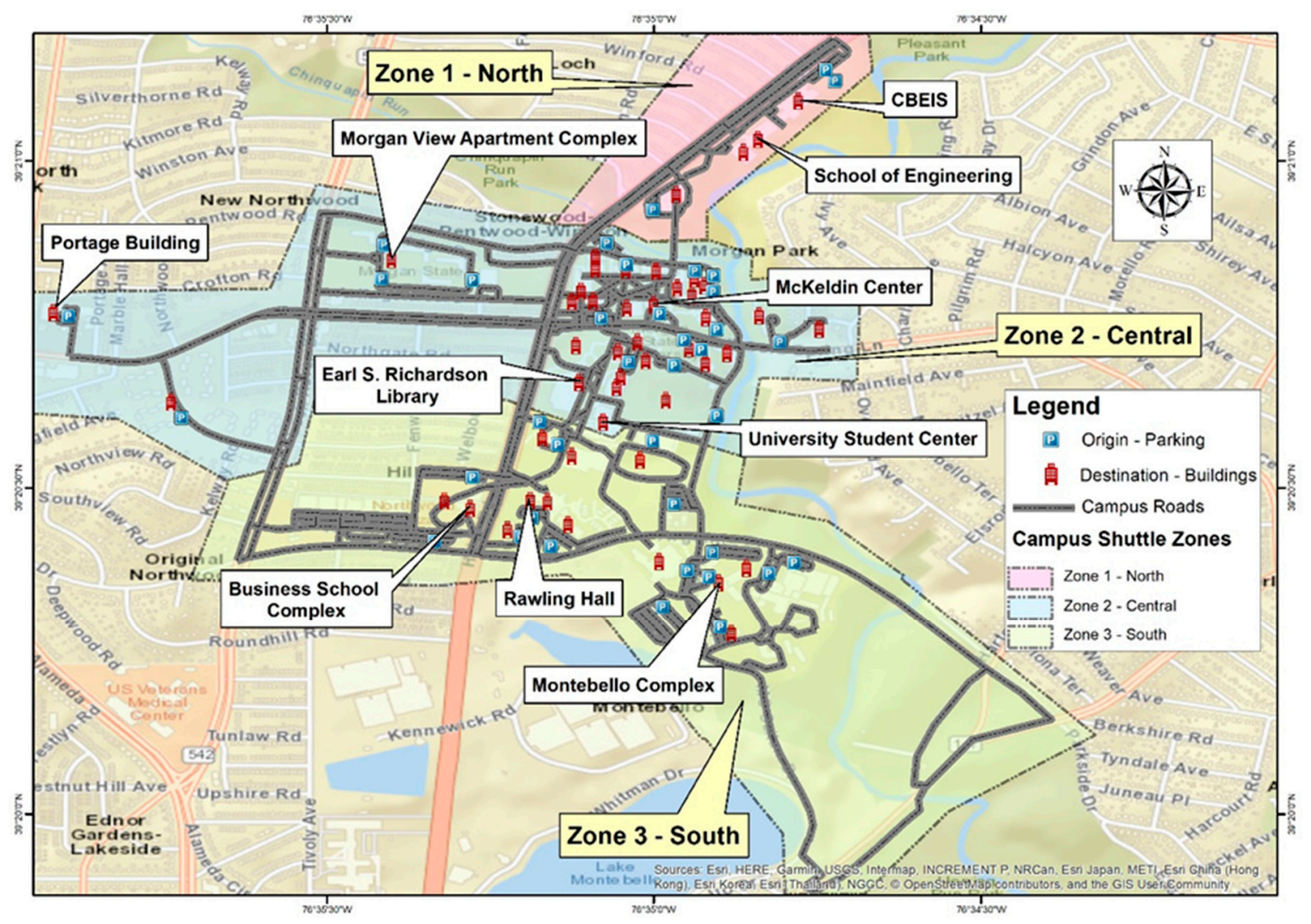

Figure 2. Study Area Map-Morgan State University, Baltimore, Maryland.

\subsection{Data Acquisition and Preparation}

The data acquisition process for this study was based on secondary sources. Location of the origin and destination points needed to run the O-D matrix along with the necessary data (services and departments) were extracted from a 3D map provided on the Morgan State University website. It is necessary to have an error-free road network to run the O-D Matrix as a network dataset on a GIS platform. The road network dataset was extracted from the open street map website. Topology tool from ArcGIS network analyst was used with the criteria: 'must not overlap,' 'must not have pseudo nodes', and 'must not have dangle' to make the road network error-free to run the O-D matrix. The enrollment and employment statistics from 2015-2018 was made available to the authors by the Morgan State University administration office.

\section{Origin-Destination Matrix Development and Analysis}

\subsection{Identifying Suitable Locations}

A generic flow diagram showing the methodology used in this study is shown in Figure 3. 


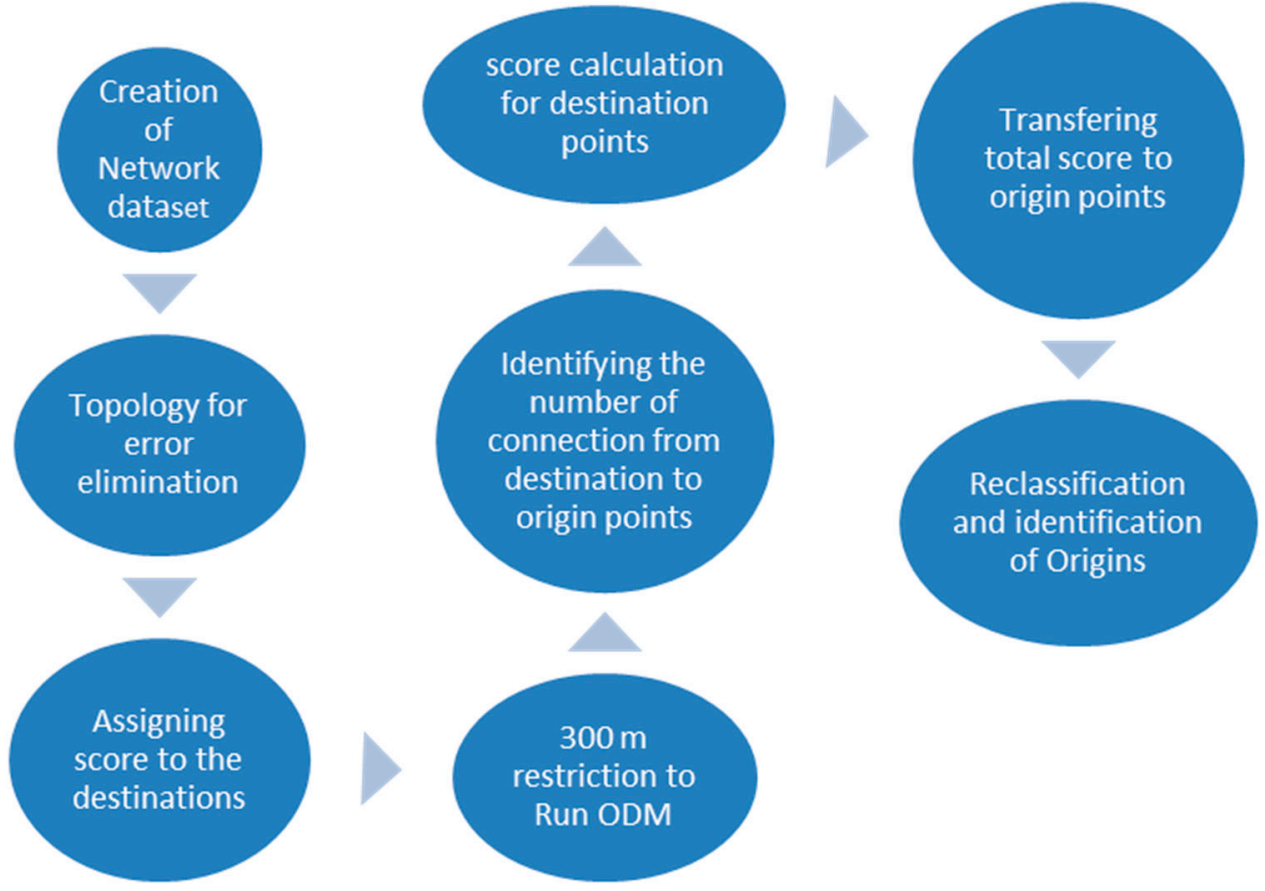

Figure 3. Flow diagram of the study methodology.

For identifying suitable locations for the Morgan State University bike-share stations, an O-D matrix was developed using ArcGIS, a geospatial analysis platform. In general, an O-D matrix is necessary for planning an excellent public transportation system [42]. There are a couple of studies which indicate that, the provision of sufficient number of bike stations increases bike usage [2,43]. Researchers like Zhou et al. [37] conducted their research by visualizing the large-scale movement data of the bike's origin and destination to identify the correlation of the O-D flows. He et al. [36] also used origin-destination data in a simple line clustering method, to analyze the applications of bike-sharing movement data. Their approach was effective in discovering clusters at different scales and can be applied to different O-D data to make pattern recognition less complex and easy to comprehend. According to Ekowicaksono [42], an O-D matrix helps identify the movements in a confined area and plays a vital role in public transportation planning. In this study, several factors were considered for the origin and destination points. Factors considered were the university population movement and services provided at the destination points, readily available spaces for establishing the bike docks for the new bike-share locations, distance from the destination and center of the campus, and zone-wise lack of frequent shuttle service. On an average, people are not usually willing to walk more than four blocks which amounts to approximately $300 \mathrm{~m}$ [44]. Keeping this in mind, a maximum walking distance of $300 \mathrm{~m}$ was chosen as an appropriate distance for candidate locations for bike stations, from prospective university buildings to travel to their respective destinations. This study was conducted based on the idea of a gravity model, where one can select one or more specific locations out of a number of origin and destination locations based on interdependent determining factors-i.e., service, population, distance, etc.-within a standard sized service area. The factors will determine the attraction score for the destination points and the location of these within the service area of origin points will eventually recommend the result of the selection.

In this study, the buildings were considered as destinations depending on the number of departments and services that are attracting the student, faculty, and staff populations. On the other hand, availability of multiple open-air parking spaces, readily available for establishing bike-share stations to minimize cost were considered as the origin points, where users can pick up and drop off the bikes. The output of the O-D matrix is shown in Figure 4. 


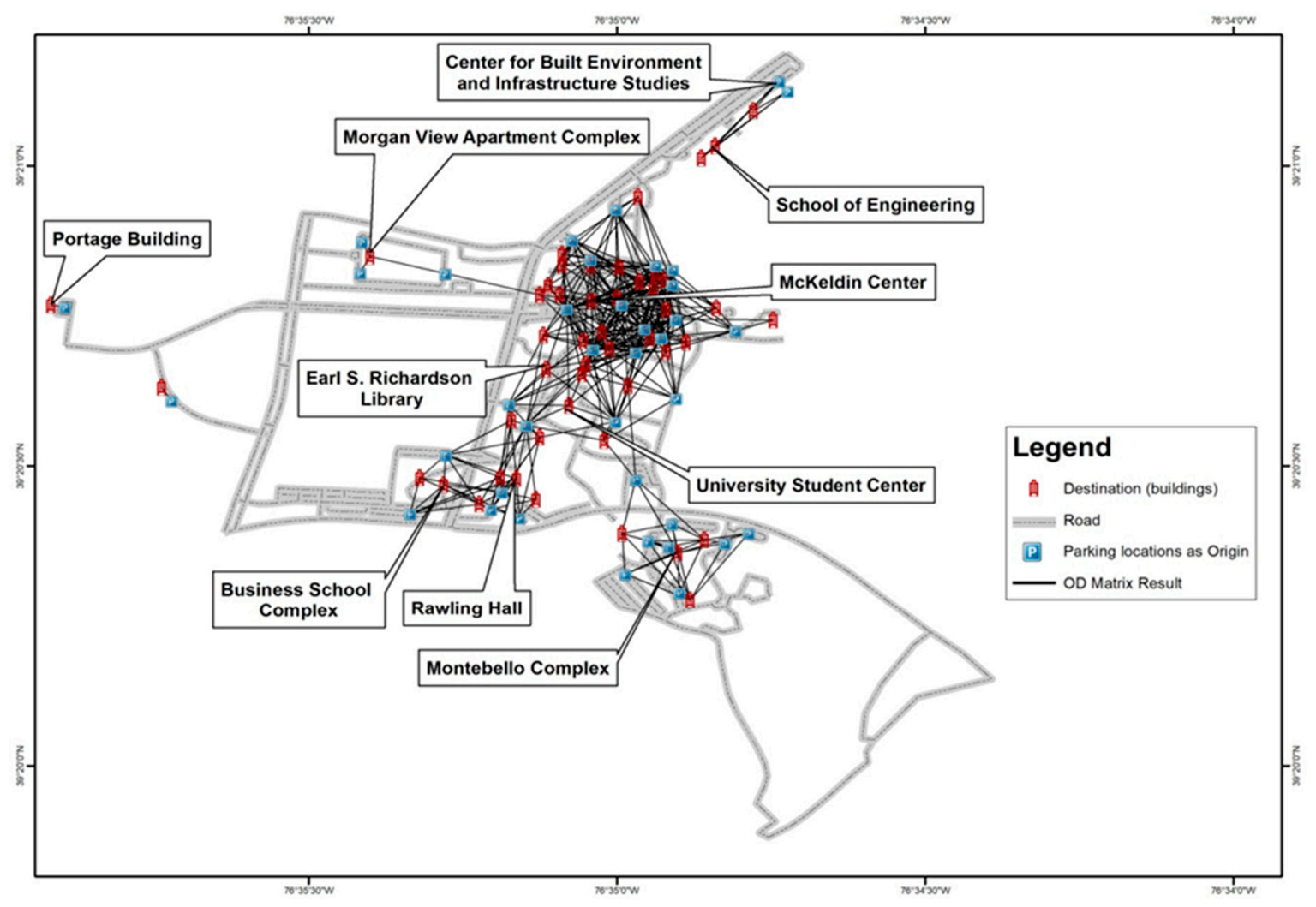

Figure 4. Connections built within $300 \mathrm{~m}$ from O-D matrix analysis.

\subsection{Score Calculation}

Calculations of the scores were needed to identify a suitable location for establishing bike-share docks. Depending on the multiple dependent factors, three types of scores were calculated for these two O-D datasets within three zones; North, Central, and South, following the zonal distribution of the campus shuttle. Firstly, the score of the buildings (destination) was calculated depending on the number of departments housed in the building and the number of services available. The second type of score was assigned to the destinations based on the population of the buildings. The third score was provided to the origin points (parking locations) considering the distance from the center of the university campus. Therefore, depending on the connection between origin and destination, final scores were calculated for the origin points in the three zones. A list of services considered for this study is shown in Table 2.

The normalized value of each building because of population, services, and distance was transferred as the total score for the origin points with maximum coverage. The formula applied to measure the value $\left(D_{1}, D_{2} \ldots ..\right)$ of each destination is

$$
D=\frac{P}{P_{\max }}+\frac{S}{S_{\max }}
$$

where,

$P=$ Number of departments in each building;

$S=$ Number of services that can be accessed in each building. 
$P_{\max }$ and $S_{\max }$ were used to normalize the values for getting a standardized measure. Calculating the destination score, it was transferred to the origin point $\left(\mathrm{O}_{1}, \mathrm{O}_{2} \ldots\right)$ along with the distance of that point from the center of the campus. The formula is given below

$$
O=\left(D_{1}+D_{2}+\ldots+D_{n}\right)+\frac{d}{d_{\max }}
$$

where,

$d=$ Distance of origin points from the center of the campus

Table 2. Name of the services provided in the buildings of Morgan State University.

\begin{tabular}{|c|c|c|}
\hline No & Name of the Services & Description \\
\hline 1 & Administrative Office & $\begin{array}{l}\text { This includes offices like Admissions, Finance, Record \& } \\
\text { Registrar, BearCard (ID, Parking, Access etc), Business \& } \\
\text { Auxilary Services, International Student \& Faculty services, } \\
\text { Bursar, Telecommunication etc }\end{array}$ \\
\hline 2 & Schools and Colleges & $\begin{array}{l}\text { The Schools \& Colleges include School of Engineering, School } \\
\text { of Architecture \& Planning, College of Liberal Arts, School of } \\
\text { Business Administration, School of Global Journalism; School } \\
\text { of Computer, Mathematics \& Natural Science, School of } \\
\text { Social Work. }\end{array}$ \\
\hline 3 & Advising & $\begin{array}{l}\text { Under the student development program, the Advising } \\
\text { service includes Highlighting the Academic Success \& } \\
\text { Achievement to inspire students, Entreprenuer development \& } \\
\text { Assistance, Student Enrichment Program, Writing center, } \\
\text { Supporting students in preparation for College. }\end{array}$ \\
\hline 4 & Divisions & $\begin{array}{l}\text { Finance \& Management, Enrollment Management \& Student } \\
\text { Success, Planning \& Information Technology, Reseach \& } \\
\text { Economic Development, Student Affairs. }\end{array}$ \\
\hline 5 & Campus Housing & $\begin{array}{l}\text { Campus housing service provides residence facilities to the } \\
\text { undergraduate and graduate students from out of state, local } \\
\text { as well as international. }\end{array}$ \\
\hline 6 & $\begin{array}{l}\text { Campus Services (i.e., ATM, } \\
\text { LAB, Dining, Health Center, } \\
\text { Shop, etc.) }\end{array}$ & $\begin{array}{l}\text { For a full functioning campus several services are needed for } \\
\text { students, faculties and staff. Services included as campus } \\
\text { service are ATM \& Banking, Health Center, Shop, LAB, Dining, } \\
\text { Cafetaria, Recreational Center, Counselling Center, Gymasium, } \\
\text { Field, Chapel. }\end{array}$ \\
\hline 7 & $\begin{array}{l}\text { Points of Interest (i.e., campus } \\
\text { highlights, arts, etc.) }\end{array}$ & $\begin{array}{l}\text { In every campus, few points are considered as important } \\
\text { locations where population movement is maximum during } \\
\text { different times. These points of interest consist of Art Galleries, } \\
\text { Dance Studio, Student Center Circle, Student Clubs, } \\
\text { University Museum (Morgan State University being a } 152 \\
\text { years old Historical Educational Institute). }\end{array}$ \\
\hline 8 & Transit Stops & $\begin{array}{l}\text { Transit stops include stops of campus shuttle and college } \\
\text { town shuttle. }\end{array}$ \\
\hline
\end{tabular}

All the destination scores that are connecting each origin point were summed together with the normalized distance value of that origin point to identify the value of that point. The scores were based on distance, the population of the buildings and services available at the buildings and shuttle stops at the building. The population covered by each Origin point is shown in Figure 5. 


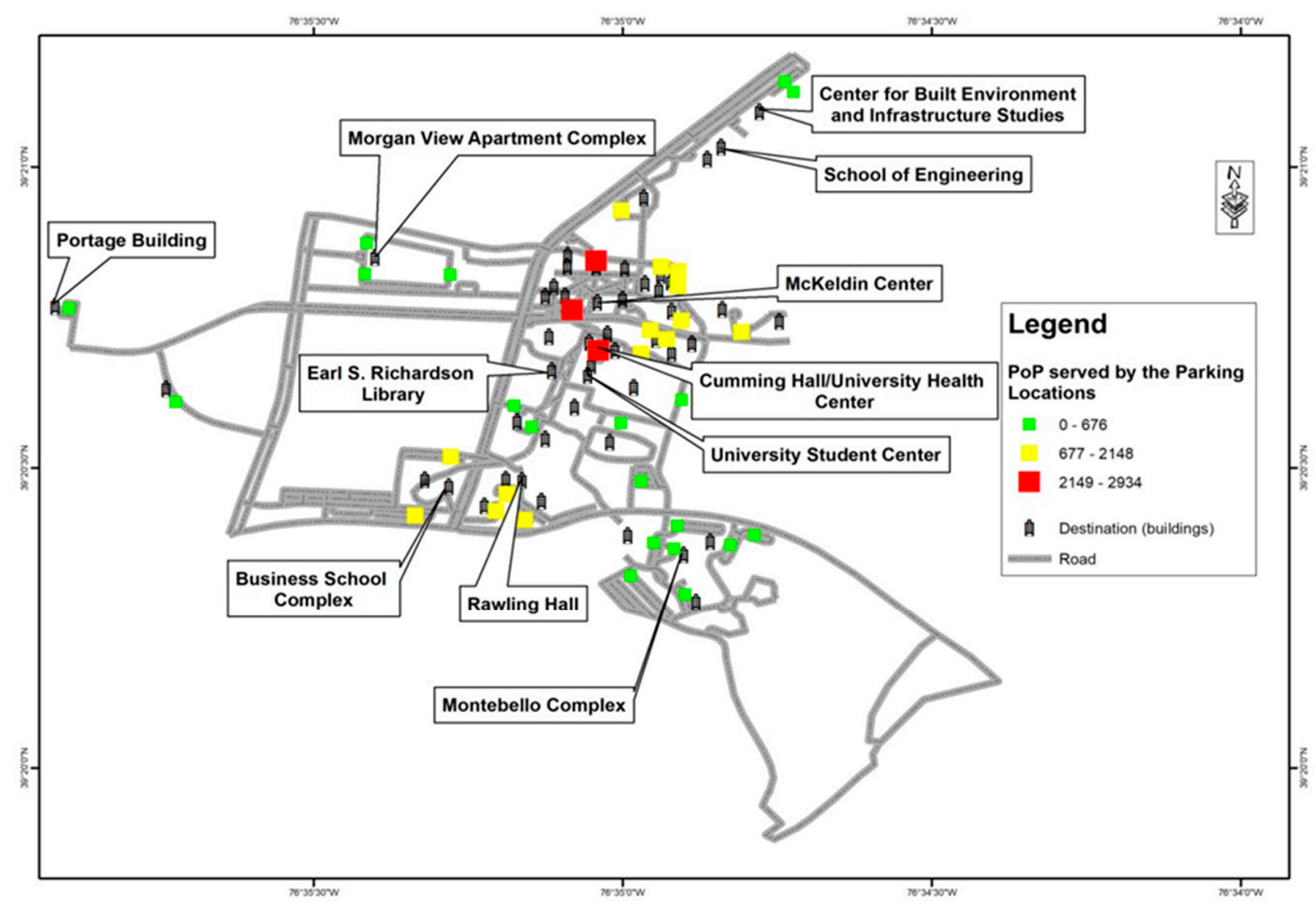

Figure 5. Population classification served by each origin point.

Finally, the total suitability score of the origin points in all three zones were calculated. These are just arbitrary numbers based on normalized values and thus the three highest scores from the North, Central, and South zones were selected as suitable locations for establishing bike-share stations for the students, faculty, and staff of Morgan State University. Figure 6 shows a flow diagram of the suitability score calculation process.

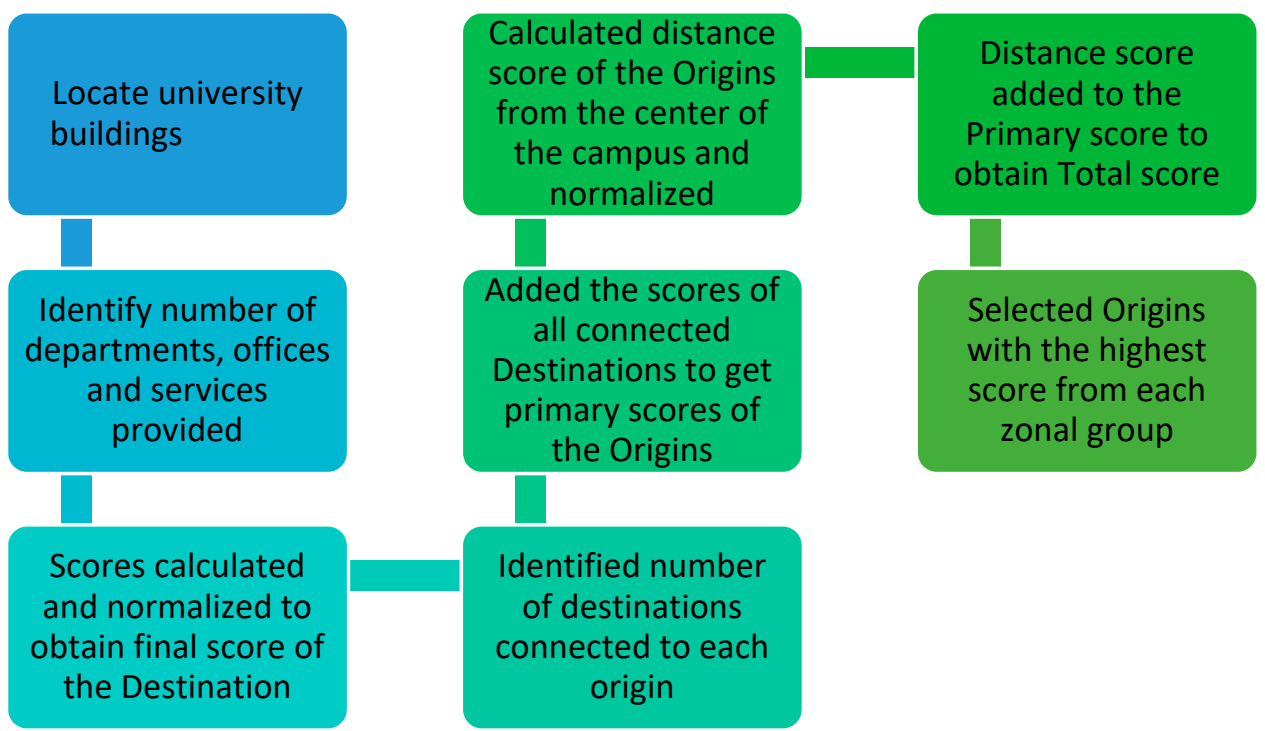

Figure 6. Flow diagram of suitability score calculation process.

Table 3 provides a sample snapshot of the scores along with the campus population served at the origin points. 
Table 3. Sample snapshot of score and campus population served by zone.

\begin{tabular}{ccccccc}
\hline No. & Building Name & $\begin{array}{c}\text { Total Score from } \\
\text { Departments \& } \\
\text { Services }\end{array}$ & $\begin{array}{c}\text { Distance Score of the } \\
\text { Origin Point from the } \\
\text { Center of the Campus }\end{array}$ & $\begin{array}{c}\text { Suitability } \\
\text { Score } \\
\text { Subtotal }\end{array}$ & $\begin{array}{c}\text { Total Campus } \\
\text { Population } \\
\text { Served }\end{array}$ & Zone \\
\hline $\begin{array}{c}\text { Center for Built } \\
\text { Environment and } \\
\text { Infrastructure Studies }\end{array}$ & 3.05 & 0.82 & 3.87 & 676 & North \\
\hline 2 & $\begin{array}{c}\text { Clarence M. Mitchel Jr. } \\
\text { Engineering Building }\end{array}$ & 3.05 & 0.81 & 3.86 & 670 & North \\
\hline 3 & University post office & 2.7 & 0.81 & 3.51 & 95 & South \\
\hline 4 & Rawling Hall & 4.31 & 1.23 & 5.54 & 2148 & South \\
\hline 5 & University Chapel & 4.77 & 0.43 & 5.2 & 329 & South \\
\hline 6 & Communication center & 6.52 & 0.91 & 7.41 & 2038 & Central \\
\hline 7 & $\begin{array}{c}\text { George McMechen } \\
\text { Building }\end{array}$ & 10.17 & 1.01 & 11.18 & 2976 & Central \\
\hline 8 & $\begin{array}{c}\text { CummingHouse/University } \\
\text { Health Center }\end{array}$ & 11.09 & 1.11 & 12.2 & 2934 & Central \\
\hline
\end{tabular}

These selected locations not only follow the maximum coverage rules but also consider the population which is dependent upon two factors-(a) departments and (b) services. Prior studies have shown that, the weighted value of the population plays a significant role in selecting a location for bike-share services.

\section{Results and Discussion}

A number of factors like population, distance, facilities are essential in computing the normalized score of the origin and destination points. To run the O-D matrix in the GIS environment, it is necessary to specify the criteria such as cut off values, number of locations to identify and the maximum coverage area. As mentioned in prior studies [44], people are willing to walk up to $300 \mathrm{~m}$ from their origin/destination to use bike-share service. So, in this study, the maximum coverage area used was $300 \mathrm{~m}$ from the destination point, and a connection was built to the origin points within this area using the O-D matrix. Scores of the destination points added to the distance score of the origin points helped evaluate the suitable locations for the bike-share stations in each zone. All three types of scores were weighted equally to simplify the process of evaluation. Each of these scoring criterions interdependent variables that were calculated separately in this study, were finally added together to identify the final locations. The top bike-share station locations identified from each of the three zones are shown in Figure 7.

Table 4 displays the details of the selected locations for the bike-share stations. It can be seen that the number of services from the first location (Central Zone) is highest along with the number of the population served. On the other hand, the second location (South Zone) has a lower service number, but the density of the population supported at this location is comparatively very high. Similarly, although the third location (North Zone) has a lower total score compared to the first two, the distance from the center of the university was highest and this score was higher than other candidate locations. This simplified model applies fast calculation, and displays the influence of variables on each other, which has a significant impact on determining suitable bike-share station locations on a university campus. 


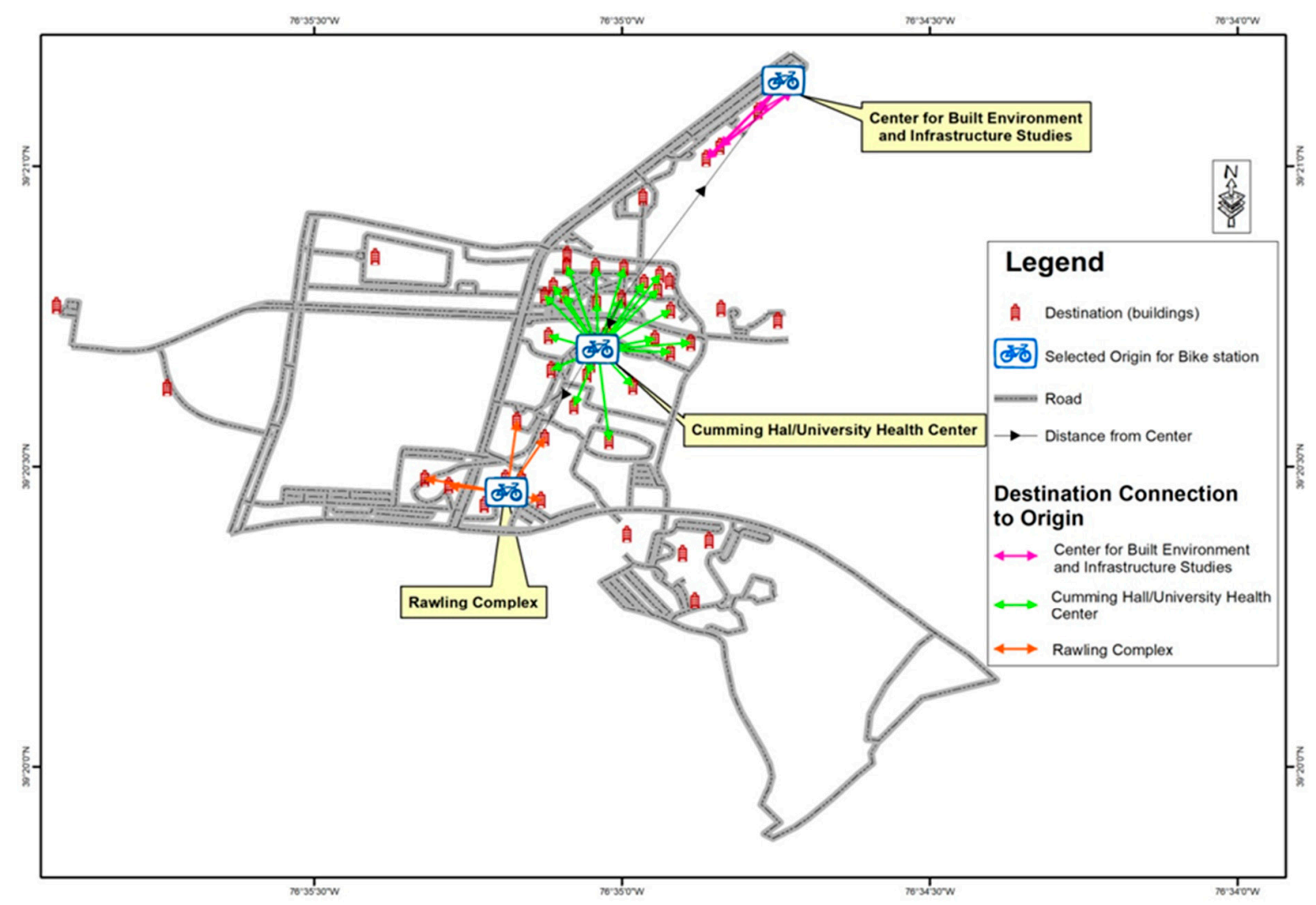

Figure 7. Selected locations for bike-share stations.

Table 4. Suitable bike station location details.

\begin{tabular}{cccccc}
\hline Location & Position & Total Score & $\begin{array}{c}\text { Number of } \\
\text { Destinations } \\
\text { Connected }\end{array}$ & Population & $\begin{array}{c}\text { Distance from the } \\
\text { Center (in Miles) }\end{array}$ \\
\hline $\mathbf{1}$ & $\begin{array}{c}\text { Cumming } \\
\text { House/University } \\
\text { Health Center }\end{array}$ & 12.20 & 25 & 2934 & 0.10 \\
\hline $\mathbf{2}$ & Rawling Hall complex & 5.54 & 8 & 2148 & 0.41 \\
\hline $\mathbf{3}$ & $\begin{array}{c}\text { Center for Built } \\
\text { Environment and } \\
\text { Infrastructure Studies }\end{array}$ & 3.87 & 3 & 676 & 0.47 \\
\hline
\end{tabular}

Location 1. (Central Zone)—Cumming Hall/University Heath Center-The land use and infrastructure pattern of Morgan State University allows available open air parking spots in this area. Within the $300 \mathrm{~m}$ surrounding this service point, there is a noticeable amount of population movement. Major facilities are the Earl S. Richardson Library, University Health Center, Student Housing, University Field, University Student Center, Bank, Administration and Admission office.

Location 2. (South Zone)—Rawling Hall-This location for a bike-share station will serve both residential and floating students as well as the people who visit university for information, financial assistance, international affairs, etc. Considering the university map, it is noticeable that this location mainly serves the population of the southern portion of the university.

Location 3. (North Zone) - Center for Built Environment and Infrastructure Studies-This is the most distant point from the center of the campus. It houses a total of eight departments, ATM booth, food kiosk, couple of conference halls, multiple computer and other engineering laboratories, one medium size open air parking lot, and a two-storeyed parking facility. A high number of student, faculty, and staff trips are available in this area as this location is serving the largest school of the University, School of Engineering. 


\section{Conclusions}

This study used an O-D matrix to identify appropriate bike-share station locations at Morgan State University. The O-D matrix used the population of each building, the distance to the center of the campus where maximum facilities, including the graduate and undergraduate offices, are located and the frequency of the university shuttle connecting most of the buildings. The score of the buildings (destination) was calculated depending on the number of departments housed and the number of services available in the building. The second type of score was assigned to the destinations based on the total number of the population using each of that. The third score calculated for the origin points (parking locations) considered the distance from the center of the university campus. The analysis results identified a total of three locations from the three zones of campus shuttle zonal service area, which will serve most of the population at Morgan State University and connect them to different facilities on campus. These three locations are appropriate to start a pilot program for a bike-share system which will able to cover most of the campus area. Once the pilot has been evaluated based on usage, additional bike-share stations can be setup using the same methodology. The methodology adopted in this study is a simple and straightforward process to identify suitable locations to establish bike share stations. This study can be replicated and used on other university campuses, depending on landuse patterns, areal extent, population, and other factors, which will help further bike-sharing programs and enhance transit on university campuses in an environmentally friendly manner.

Author Contributions: Conceptualization, N.K.K., S.B.; methodology, M.K., N.K.K., and S.B.; Data collection, M.K. and N.K.K.; Analysis and interpretation, M.K. and S.B.; Writing-review and editing, N.K.K., S.B., and M.J.; Visualization, M.K.

Acknowledgments: The authors would like to thank the administration of Morgan State University for helping provide the statistical information used in the study.

Conflicts of Interest: The authors declare no conflict of interest.

\section{References}

1. Fishman, E.; Washington, S.; Haworth, N. Erratum to Bike share: A synthesis of the literature (Transport Reviews). Transp. Rev. 2013, 33. [CrossRef]

2. Faghih-Imani, A.; Eluru, N. Analysing bicycle-sharing system user destination choice preferences: Chicago's Divvy system. J. Transp. Geogr. 2015, 44, 53-64. [CrossRef]

3. World Bike-Sharing Cities. 2019. Available online: www.bikesharingworld.com (accessed on 16 July 2019).

4. Jäppinen, S.; Toivonen, T.; Salonen, M. Modelling the potential effect of shared bicycles on public transport travel times in Greater Helsinki: An open data approach. Appl. Geogr. 2013, 43, 13-24. [CrossRef]

5. Bachand-Marleau, J.; Lee, B.H.; El-Geneidy, A.M. Better understanding of factors influencing likelihood of using shared bicycle systems and frequency of use. Transp. Res. Rec. 2012, 2314, 66-71. [CrossRef]

6. A New Direction: Our Changing Relationship with Driving and the Implications for America's Future. Available online: https://trid.trb.org/view/1250503 (accessed on 16 July 2019).

7. Studies show that bike commuting is one of the best ways to stay healthy. Available online: https: //grist.org/cities/studies-show-that-bike-commuting-is-one-of-the-best-ways-to-stay-healthy/ (accessed on 16 July 2019).

8. Best Cities for Students without Cars. Available online: https://www.bestcolleges.com/features/cities-forstudents-without-cars/ (accessed on 16 July 2019).

9. Gilpin, J. Best Practices in Campus Bicycle Planning and Program Development. Available online: https: //altaplanning.com/wp-content/uploads/campus-bicycle-planning-white-paper-alta-1.pdf (accessed on 16 July 2019).

10. Kaplan, D.H. Transportation sustainability on a university campus. Int. J. Sustain. High. Educ. 2015, 16, 173-186. [CrossRef]

11. League of American Bicyclists Bicycle Friendly University Awards. Available online: https://bikeleague.org/ sites/default/files/BFU_Award_List_2018_ALL.pdf (accessed on 16 July 2019).

12. Active Commuting. Available online: http://bike.hwb.gatech.edu/active-commuting (accessed on 16 July 2019). 
13. News, U.S. Best Colleges. Available online: https://www.usnews.com/best-colleges (accessed on 16 July 2019).

14. Services, P.T. Bicycle-Sharing (Nice Ride). Available online: https://www.pts.umn.edu/bike/bike-sharingnice-ride (accessed on 16 July 2019).

15. Council, D.U.S. Bicycling at Drexel: The Definitive Guide. Available online: https://www.drexel.edu/green/ resources/Drexel\%20Resources/ \{\}/media/Files/green/newsletters/newsletter01_13.htm (accessed on 16 July 2019).

16. Big Red Bikes Is Back. Available online: https://bigredbikes.cornell.edu/ (accessed on 16 July 2019).

17. Design, A.P. California State University, Fresno-Active Transportation Plan. Available online: http://www. fresnostate.edu/adminserv/police/documents/AlternativeTransportationPlan.pdf (accessed on 16 July 2019).

18. Finance and Management-Bicycle Sharing. Available online: https://financeandmanagement.buffalostate. edu/bicycle (accessed on 16 July 2019).

19. Getting Around by Bike Map-MIT Campus. Available online: https://web.mit.edu/facilities/transportation/ docs/Getting_Around_by_Bike_map.pdf?pdf=bike-map (accessed on 16 July 2019).

20. Stude, I. Portland State University Outdoor Bike Parking. Available online: https://www.pdx.edu/bikehub/ outdoor-bike-parking (accessed on 16 July 2019).

21. University, S. Stanford University Bicycle Program Highlights. Available online: https://transportationforms.stanford.edu/pdf/BFUAward_Highlights_Final.pdf?dec5 (accessed on 16 July 2019).

22. TU locks in bike share program. Available online: http://thetowerlight.com/tu-locks-in-bike-share-program/ (accessed on 16 July 2019).

23. Webster University Bike Share. Available online: http://bike.webster.edu/ (accessed on 16 July 2019).

24. Sullivan, C. Yale Bike Map. Available online: https://to.yale.edu/bike-rack-map (accessed on 16 July 2019).

25. Ashley, J. Bike sharing as alternative transportation at Bridgewater State University. Undergrad. Rev. 2012, 8, $16-25$.

26. Tufts University Rolls Out Bike Share Program. Available online: https://patch.com/massachusetts/somerville/ tufts-university-rolls-out-bike-share-program (accessed on 16 July 2019).

27. Bike-sharing programs spin across U.S. campuses. Available online: https://usatoday30.usatoday.com/news/ education/2010-09-21-college-bike-sharing_N.htm (accessed on 16 July 2019).

28. Lin, J.-R.; Yang, T.-H. Strategic design of public bicycle sharing systems with service level constraints. Transp. Res. Part E Logist. Transp. Rev. 2011, 47, 284-294. [CrossRef]

29. Shu, J.; Chou, M.; Liu, Q.; Teo, C.-P.; Wang, I.-L. Bicycle-Sharing System: Deployment, Utilization and the Value of Re-Distribution; National University of Singapore-NUS Business School: Singapore, 2010.

30. ReVelle, C.S.; Eiselt, H.A. Location analysis: A synthesis and survey. Eur. J. Oper. Res. 2005, 165, 1-19. [CrossRef]

31. Daskin, M.S. What you should know about location modeling. Nav. Res. Logist. 2008, 55, 283-294. [CrossRef]

32. Chen, L.; Zhang, D.; Pan, G.; Ma, X.; Yang, D.; Kushlev, K.; Zhang, W.; Li, S. Bike sharing station placement leveraging heterogeneous urban open data. In Proceedings of the 2015 ACM International Joint Conference on Pervasive and Ubiquitous Computing, Osaka, Japan, 7-11 September 2015; pp. 571-575.

33. Frade, I.; Ribeiro, A. Bicycle sharing systems demand. Procedia-Soc. Behav. Sci. 2014, 111, 518-527. [CrossRef]

34. Martinez, L.M.; Caetano, L.; Eiró, T.; Cruz, F. An optimisation algorithm to establish the location of stations of a mixed fleet biking system: An application to the city of Lisbon. Procedia-Soc. Behav. Sci. 2012, 54, 513-524. [CrossRef]

35. García-Palomares, J.C.; Gutiérrez, J.; Latorre, M. Optimizing the location of stations in bike-sharing programs: A GIS approach. Appl. Geogr. 2012, 35, 235-246. [CrossRef]

36. He, B.; Zhang, Y.; Chen, Y.; Gu, Z. A simple line clustering method for spatial analysis with origin-destination data and its application to bike-sharing movement data. ISPRS Int. J. Geo-Inf. 2018, 7, 203. [CrossRef]

37. Zhou, Z.; Meng, L.; Tang, C.; Zhao, Y.; Guo, Z.; Hu, M.; Chen, W. Visual abstraction of large scale geospatial origin-destination movement data. IEEE Trans. Vis. Comput. Graph. 2018, 25, 43-53. [CrossRef] [PubMed]

38. Nickkar, A.; Banerjee, S.; Chavis, C.; Bhuyan, I.A.; Barnes, P. A spatial-temporal gender and land use analysis of bikeshare ridership: The case study of Baltimore City. City Cult. Soc. 2019, 100291. [CrossRef]

39. Bike Share Station Siting Guide. Available online: https://nacto.org/wp-content/uploads/2016/04/NACTOBike-Share-Siting-Guide_FINAL.pdf (accessed on 16 July 2019).

40. U.S. News Rankings-Morgan State University. Available online: https://www.usnews.com/best-colleges/ morgan-state-2083 (accessed on 16 July 2019). 
41. Morgan View Campus Apartments. Available online: https://www.morganview.com/student-apartments/ $\mathrm{md} /$ baltimore/morgan-view (accessed on 16 July 2019).

42. Ekowicaksono, I.; Bukhari, F.; Aman, A. Estimating Origin-destination Matrix of Bogor City Using Gravity Model. In IOP Conference Series: Earth and Environmental Science; IOP Publishing: Bristol, UK, 2016; p. 012021.

43. Wang, X.; Lindsey, G.; Schoner, J.E.; Harrison, A. Modeling bike share station activity: Effects of nearby businesses and jobs on trips to and from stations. J. Urban Plan. Dev. 2015, 142, 04015001. [CrossRef]

44. DeMaio, P. Bike-sharing: History, impacts, models of provision, and future. J. Public Transp. 2009, 12, 3. [CrossRef]

(C) 2019 by the authors. Licensee MDPI, Basel, Switzerland. This article is an open access article distributed under the terms and conditions of the Creative Commons Attribution (CC BY) license (http://creativecommons.org/licenses/by/4.0/). 